University of Nebraska - Lincoln

DigitalCommons@University of Nebraska - Lincoln

Papers in the Earth and Atmospheric Sciences Earth and Atmospheric Sciences, Department

2005

\title{
In memoriam: John Platt Bradbury (1936-2005)
}

Walter Dean

US Geological Survey, Denver, CO, dean@usgs.gov

Sherilyn C. Fritz

University of Nebraska-Lincoln, sfritz2@unl.edu

Cathy Whitlock

Montana State University - Bozeman, whitlock@unca.edu

William Watts

Trinity College, Dublin

Follow this and additional works at: https://digitalcommons.unl.edu/geosciencefacpub

Part of the Earth Sciences Commons

Dean, Walter; Fritz, Sherilyn C.; Whitlock, Cathy; and Watts, William, "In memoriam: John Platt Bradbury (1936-2005)" (2005). Papers in the Earth and Atmospheric Sciences. 123.

https://digitalcommons.unl.edu/geosciencefacpub/123

This Article is brought to you for free and open access by the Earth and Atmospheric Sciences, Department of at DigitalCommons@University of Nebraska - Lincoln. It has been accepted for inclusion in Papers in the Earth and Atmospheric Sciences by an authorized administrator of DigitalCommons@University of Nebraska - Lincoln. 


\title{
In memoriam: John Platt Bradbury (1936-2005)
}

\author{
Walter Dean ${ }^{1, *}$, Sheri Fritz ${ }^{2}$, Cathy Whitlock ${ }^{3}$ and William Watts ${ }^{4}$ \\ ${ }^{1}$ US Geological Survey, Federal Center, Box 25046, MS980, Denver, CO 80225, USA; ${ }^{2}$ Department of \\ Geosciences, University of Nebraska, Lincoln, NE 68588, USA; ${ }^{3}$ Department of Earth Sciences, Montana \\ State University, Bozeman, MT 59717, USA; ${ }^{4}$ School of Botany, Trinity College, Dublin 2, Ireland; *Author \\ for correspondence (e-mail: dean@usgs.gov)
}

John Platt Bradbury, a former United States Geological Survey (USGS) geologist, and a long time and much valued editorial board member for the Journal of Paleolimnology, died of cancer (abdominal mesothelioma) on August 15, 2005, in the $\log$ home that he and his wife Vera Markgraf built in the mountains near Monte Vista, Colorado. Platt's interest in paleolimnology developed during his graduate school years at the University of New Mexico, working with Roger Anderson and Walt Dean. He received his Ph.D. in 1967. He went on to do post-doctoral research at Yale University under G. Evelyn Hutchinson and then became an Assistant Professor at the University of Minnesota Limnological Research Center, where, among other projects, he worked on a multidisciplinary study of the Klutlan Glacier, Yukon Territory (Bradbury and Whiteside 1980). In 1975, he joined the Paleontology and Stratigraphy Branch of the USGS, where he offered a primary specialty in continental diatoms and secondary specialty in Quaternary palynology. Platt's work focused on developing a continental diatom biostratigraphy for Miocene through Quaternary sediments and on paleoclimatic reconstructions from lacustrine records.

Platt had wide-ranging interests and talents within the fields of diatom studies, paleolimnology, and paleoclimatology, and his research areas included North America, South America, Australia, and Asia. He was the author or coauthor of over 100 publications. He had a keen eye for detail and was serious about diatom taxonomy, faithfully describing the messy complex of Stephanodiscus species that inhabited nutrient-enriched Minnesota lakes (Bradbury 1975) and the diatoms of Neogene and Quaternary fossil deposits, together with colleagues Ed Theriot and
Bill Krebs (Krebs et al. 1987; Theriot and Bradbury 1987; Bradbury and Krebs 1995). He even created a taxonomic shorthand for common western diatoms, so that his non-diatom colleagues could recognize and gain ecological information from the 'beer-can diatom' (Aulacoseira) or the 'potato-chip diatom' (Campylodiscus). He was a

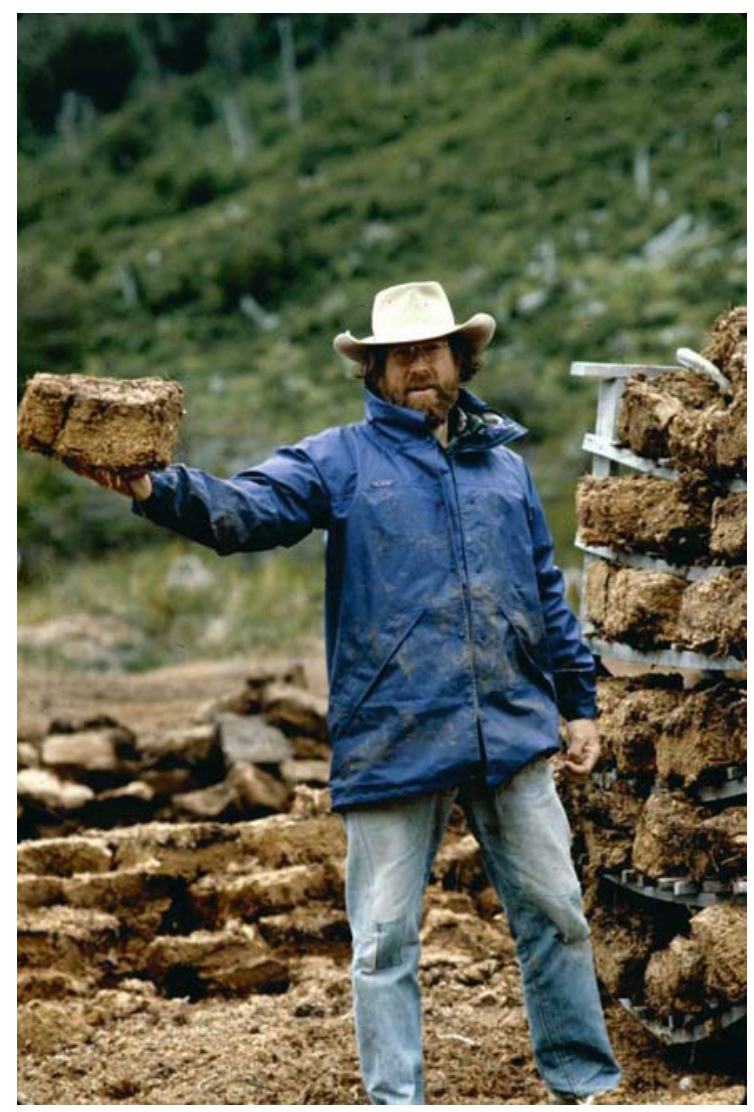

Platt cutting peat in Tierra del Fuego (Photo by Vera Markgraf). 


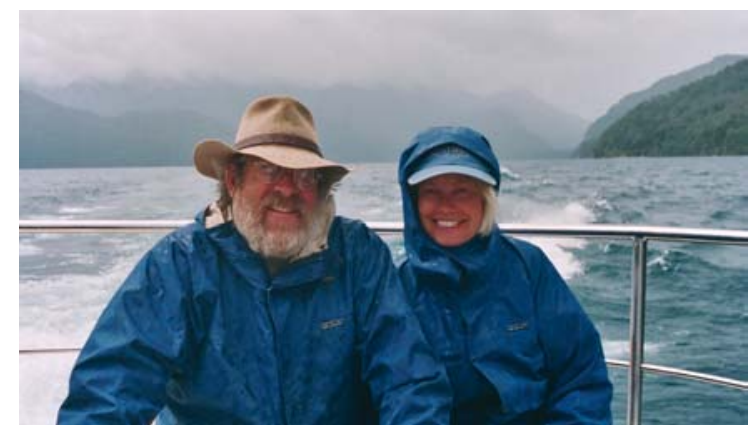

Platt and Vera on Lago Menéndez, Argentina, February 2002 (Photo by Cathy Whitlock).

true pioneer in the paleolimnological community and was responsible for classic studies describing human impact on North American lakes (Bradbury 1975; Bradbury and Winter 1976; Bradbury et al. 2004a); long Quaternary records of large lake systems in western North America (Bradbury et al. 1989, 2004b; Bradbury 1991, 1997); the complexities of climatic interpretation from fossil diatom records (Bradbury 1988, 1989); and the studies of Elk Lake, Minnesota, that set the stage for our current emphasis on high-resolution analyses and the use of multiple proxies for interpretation of environmental history (Bradbury and Dean 1993).

Platt also took a life-long pleasure in Latin America and its cultures, and he spoke Spanish well and traveled widely. He studied aspects of the Basin of Mexico (Watts and Bradbury 1982; Bradbury 1989, 2002), and after retirement in 1999, he and Vera worked together on the paleoclimatic history of South America (Bradbury et al. 2001; Markgraf et al. 2003).

Platt's many friends will dearly miss him. He was a true individualist, who will be remembered for his often acerbic wit and humor; his creativity as a scientist, woodworker, and blacksmith; and his sense of adventure. We will miss his hospitality at their cabin and those evenings talking about life, love, and science over home-made chokecherry wine. He is survived by his wife Vera; daughter Kate of Wheatridge, Colorado; son, John Wymond of St. Helena, California; stepdaughter Michelle of Denver, Colorado; and four grandchildren.

\section{References cited}

Bradbury J.P. 1975. Diatom stratigraphy and human settlement in Minnesota. Geol. Soc. Amer. Boulder, Colorado, USA, Sp. Paper 171: 1-74.
Bradbury J.P. 1988. A climatic limnologic model of diatom succession for paleolimnological interpretation of varved sediments at Elk Lake, Minnesota. J. Paleolimnol. 1: 115-131.

Bradbury J.P. 1989. Late Quaternary lacustrine paleoenvironments in the Cuenca de Mexico. Quat. Sci. Rev. 8: 75-100.

Bradbury J.P. 1991. The late Cenozoic diatom stratigraphy and paleolimnology of Tule Lake, Siskiyou Co., California. J. Paleolimnol. 6: 205-255.

Bradbury J.P. 1997. A diatom record of climate and hydrology for the past $200 \mathrm{ka}$ from Owens Lake, California with comparison to other Great Basin records. Quat. Sci. Rev. 16: 203-219.

Bradbury J.P. 2002. Limnologic history of Lago de Patzcuaro, Michoacan, Mexico for the past 48,000 years: impacts of climate and man. Palaeogeog. Palaeoclimat. Palaeoecol. 163: 69-95.

Bradbury J.P. and Dean W.E. 1993. Elk Lake, Minnesota: Evidence for Rapid Climate Change in the North-Central United States. Geol. Soc. Amer. Boulder, Colorado, USA, Sp. Paper 276: 1-336.

Bradbury J.P. and Krebs W.N. 1995. The diatom genus Actinocyclus in the western United States. U.S. Geol. Survey Prof. Paper 1543A-B: 1-73.

Bradbury J.P. and Whiteside M.C. 1980. Paleolimnology of two lakes in the Klutlan Glacier region, Yukon Territory, Canada. Quat. Res. 14: 149-168.

Bradbury J.P. and Winter T.C. 1976. Areal distribution and stratigraphy of diatoms in the sediments of Lake Sallie, Minnesota. Ecology 57: 1005-1014.

Bradbury J.P., Forester R.M. and Thompson R.S. 1989. Late Quaternary paleolimnology of Walker Lake, Nevada. J. Paleolimnol. 1: 249-267.

Bradbury J.P., Grosjean M., Stine S. and Sylvestre F. 2001. Full and Late Glacial lake records along the PEP 1 transect: their role in developing interhemispheric paleoclimate interactions. In: Markgraf V. (ed.), Interhemispheric Climate Linkages. Academic Press, Boulder, Colorado, USA, pp. 265-292.

Bradbury J.P., Colman S.M. and Reynolds R.L. 2004a. The history of recent limnological changes and human impact on Upper Klamath Lake, Oregon. J. Paleolimnol. 31: 151-165.

Bradbury J.P., Colman S.M. and Dean W.E. 2004b. Limnological and climatic environments at Upper Klamath Lake, Oregon during the past 45,000 years. J. Paleolimnol. 31: 167-188.

Krebs W.N., Bradbury J.P. and Theriot E. 1987. Neogene and Quaternary lacustrine diatom biochronology, western USA. Palaios 2: 505-513.

Markgraf V., Bradbury J.P., Schwalb A., Burns S.J., Stern C., Ariztegui D., Gilli A., Anselmetti F.S., Stine S. and Maidana N. 2003. Holocene palaeoclimates of southern Patagonia: limnological and environmental history of Lago Cardiel, Argentina. Holocene 13: 581-591.

Theriot E. and Bradbury J.P. 1987. Mesodictyon, a new fossil genus of the centric diatom family Thalassiosiraceae from the Miocene Chalk Hills Formation, western Snake River Plain, Idaho. Micropaleontology 33: 356-367.

Watts W.A. and Bradbury J.P. 1982. Paleoecological studies at Lake Patzcuaro on the west-central Mexican Plateau and at Chalco in the Basin of Mexico. Quat. Res. 17: 56-70. 